\title{
Dust Inhalation System for Small Laboratory Animals
}

\author{
Tadashi NEGISHI and Izumi NISHIMURA \\ Biology Department, Central Research Institute of Electric Power Industry, 1646 \\ Abiko, Abiko-shi, Chiba 270-11, Japan
}

(Received 14 July 1992/Accepted 27 November 1992)

\begin{abstract}
In order to stabilize the dust concentration for animal inhalation studies, two feedback systems were introduced. Dusts generated were passed through two cyclone separators and stored first in a storage chamder. Then they were aspirated into an ejector by compressed carrier air, mixed with filtered room air in a mixing box, and introduced into an exposure chamber. The first feedback system was for dust generation. Dusts were reaerosolized by on-off control using the output signals from a light-scattering dust detector connected to a storage chamber. The second system was for the control of compressed carrier air flow into an ejector. Compressed air flow was automatically regulated by a PID-controller in combination with a mass flow controller. The PID-controller processed continuous signals from another dust detector connected to an exposure chamber and fed control signals to a mass flow controller for regulation of the compressed air flow. This automatic control system could not only reduce hunchings of dust concentration following on-off control of a dust generator but also reduce overshooting of dust concentration in the exposure chamber following the detachment and dispersion of dusts adhering to the inner walls of the dust-supplying route. The system could also maintain a desired dust concentration in the exposure chamber for up to 180 days $(20 \mathrm{hr} /$ day, 7 days/week). In addition, this system could simultaneously introduce different doses of dust to other exposure chambers stably while maintaining similar size distribution of the dusts if additional identical exposure units were used. These results indicate that this dust inhalation system is suitable both for long -term studies and for investigating a dose-response relationship. - KEY WORDS : dust, inhalation system, small laboratory animal
\end{abstract}

It is well known that lung responses to inhaled particles, such as the number and composition of lung-free cells in the alveoli, depend upon not only the cytotoxicity of the particles but also the total amount of deposited particles $[1,3,5,6,10,11]$. The amount of deposited particles in the lungs depends upon the mass concentration. On the other hand, both regional and interlobar deposition of inhaled particles varies markedly with respect to particle size [7-9]. Therefore, it is important to keep the mass concentration and the distribution of particle size in the exposure chamber stable for studying the effects of respirable aerosols on health. Furthermore, automatic operation of the exposure system is required, especially for long-term inhalation studies.

Generally test aerosols are generated continuously or by on-off control with monitoring of the concentration in the exposure chamber.
They are diluted with filtered clean air in a mixing box and introduced into an exposure chamber.

The concentration of gaseous substances can be regulated constantly by using a mass flow controller, which is an automatic gas flow regulatory device independent of pressure and temperature. However, it is difficult to maintain a stable dust concentration since constant generation of dust aerosols cannot be easily achieved [2]. For this reason dust aerosols are usually generated by an on-off control system.

Hirano [4] reported that acid mist aerosols could be controlled at the desired concentration for up to 8 hours automatically. In his system mists were generated by a nebulizer at a constant rate, mixed with filtered air in a mixing box, then introduced into an exposure chamber. Mist concentraion in the exposure chamber was controlled by exhaust air flow from the 
mixing box through an ejector to outside the system by compressed air. A PID-controller combined with a mass flow controller was used to regulate the compressed air flow automatically in his system.

The PID-controller is an electronic regulatory device commonly used for thermal control such as in electric furnaces. This controller incorporates three control action modes. These are called proportional (P), integral (I) or reset, and derivative (D) or rate action. $\mathrm{P}$-action gives an output proportional to the measured variables in the proportional band (percent to a set point stored in the controller). A narrow band causes hunchings; on the other hand a wide band causes an offset which means a shift of the measured variables away from a set point. The purpose of the I -action is to eliminate the offset. This action gives continuous output signals in the proper direction to correct the offset based on the integrated values of the control error measured during a unit time (integral time). D-action is commonly used in combination with $\mathrm{P}-$ and I -action. Output signals of $\mathrm{D}$-action are based on the rate of change of the measured variables during a unit time (derivative time). Thus D -action gives a phase lead and is useful when the control variables tend to change from time to time or in the face of sudden disturbances. There are optimum values of proportional band, integral and derivative time for the stable control in contoroling each process. Briefly, regulatory signals from this controller are automatically determined by the difference between a set point and measured variables ( $P$ -action), integrated values of control error (I -action) and the rate of change in measured variables ( $D$-action) during a set time.

A mass flow controller consists of a mass flow meter, a PI-controller and an electromagnetic actuator. The mass flow meter measures the mass flow rate of gas which is independent of gas pressure and temperature. Measured variables are compared with a set flow rate and the deviation is fed to a PI-controller. This controller acts on an electromagnetic actuator by $\mathrm{P}$-and $\mathrm{I}$-action modes described in PIDcontroller's mechanism. Thus the mass flow controller can quickly adjust the gas flow rate to a set rate. When a mass flow controller is used in combination with a PID-controller, continuous control signals are delivered from the PID-controller.

On-off control, one of the feedback systems, for the dust generation causes hunchings of the dust concentration. However, if another feedback system using both PID- and mass flow controllers is introduced, it would be expected to stabilize the dust concentraion in the exposure chamber. Once dusts are generated, they are stored first in a storage chamber set between the generator and a mixing box, and secondly air flow containing dusts from this storage chamber through an ejector to the mixing box is regulated by compressed carrier air under the control of the PID-and mass flow controllers. In this control system the PIDcontroller processes the output signals from a dust detector connected to the exposure chamber and feeds signals about the compressed air flow to the mass flow controller in response to both the measured variables and the changes in dust concentration in the exposure chamber.

Such a control system would reduce hunchings of dust concentration in the exposure chamber, especially by the $\mathrm{D}$-action mode of the PID-controller. This action mode would also reduce a sudden increase in concentration following the detachment and dispersion of dusts adhering to the inner wall of the dustsupplying route if compressed carrier air is used as exposure air. Furthermore, this system would shorten build-up time to a set point after the beginning of exposure, since the PID-controller feeds the maximum output to the mass flow contoroller when measured variables are not within the proportional band.

The authors have developed a new dust inhalation system including two feedback systems by installing these two controllers with modifications of Hirano's system. However, this system used compressed air as exposure carrier air but not as exhaust air.

This report describes the stability of dust concentration and other regulatory characteristics of this dust inhalation system.

\section{Materials and Methods}

Dust : Dust used in this study was coal fly ash for industrial testing No. 10 in JIS-Z 8901 (Association of Powder Process Industry and Engineering, Kyoto, Japan). This dust was air-classified to remove coarse particles larger than about $10 \mu \mathrm{m}$. The particle density was 


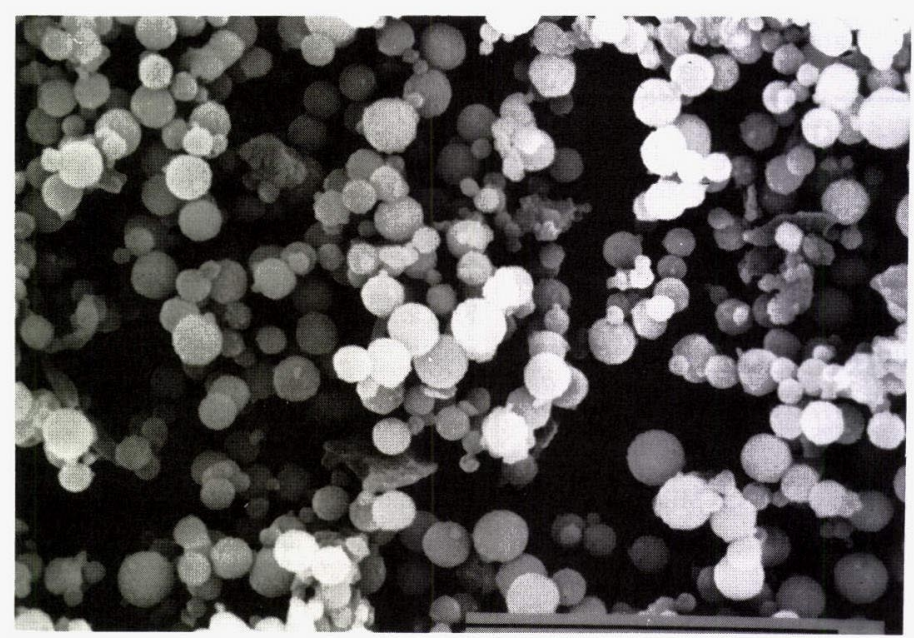

Fig. 1. Scanning electron micrograph of coal fly ash particles collected in an exposure chamber, Bar represents $10 \mu \mathrm{m}$.

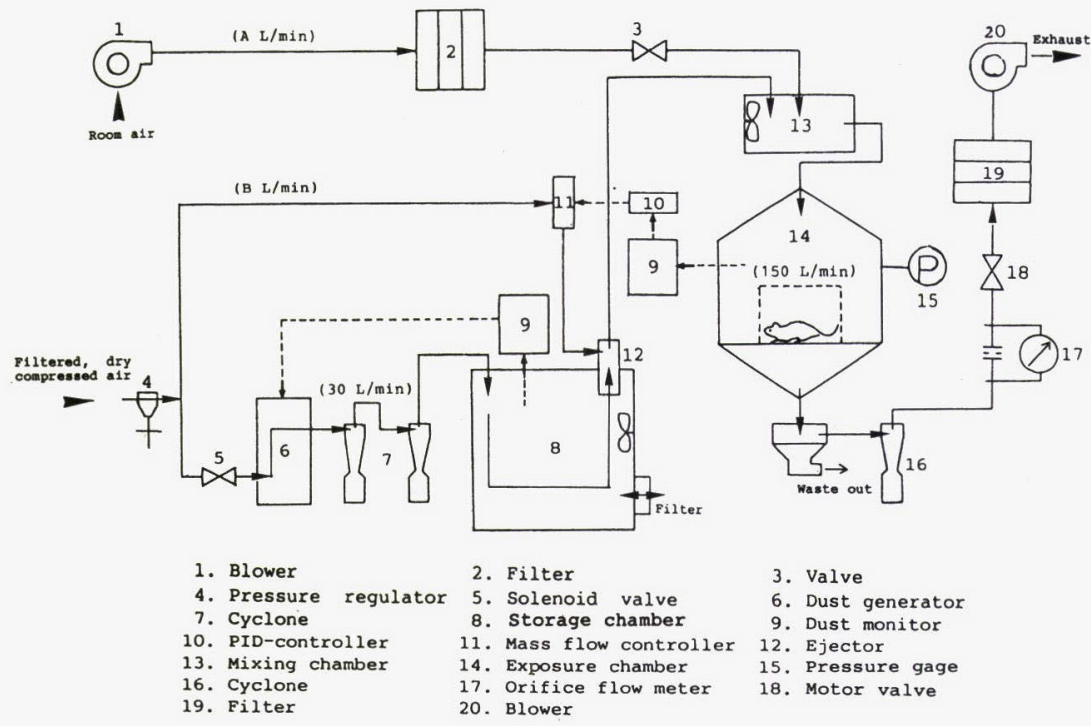

Fig. 2. Schematic diagram of the dust inhalation system. Dashed lines show the flow of regulatory feedback signals for dust generation (from 9 to 6 ) and for the regulation of compressed dust carrier air flow (from 9 to 11) from the ejector (12) to the mixing box (13). Solid lines show the air flow. Air flow rate of filtered room air for dilution (A $\ell / \mathrm{min}$ ) into the mixing box (13) is dependent on that through the ejector $(12, \mathrm{~B} \ell / \mathrm{min})$, since the air flow rate through the exposure chamber (14) is fixed at $150 \ell / \mathrm{min}$ by a motor valve (18).

about 2.0 to $2.3 \mathrm{~g} / \mathrm{cm}^{3}$. Most of the particles were spherical (Fig.1).

Exposure system: Fig. 2 shows the schematics of the dynamic air-through exposure system set for animal inhalation study. The main parts of this exposure system are a dust generator, a dust storage chamber, a mixing box, an exposure chamber, and a dust control unit for automatic control. A dust generator (Model MF-2, Sibata Scientific Technology Ltd., Tokyo, Japan) generated dust aerosols by on-off control using output signals from a 
Table 1. Materials, length and inner diameter of tubes supplying dust to the exposure chamber

\begin{tabular}{cclcc}
\hline \multicolumn{1}{c}{ Part } & \multicolumn{1}{c}{ to } & Material & $\begin{array}{c}\text { Length } \\
(\mathrm{cm})\end{array}$ & $\begin{array}{c}\text { Inner diameter } \\
(\mathrm{mm})\end{array}$ \\
\hline from & $\begin{array}{l}\text { Cyclone } \\
(5-\mu \mathrm{m} \text { cut })\end{array}$ & $\begin{array}{l}\text { Flexible } \\
\text { plastic }\end{array}$ & 30 & 15 \\
$\begin{array}{l}\text { Cyclone } \\
(5-\mu \mathrm{m} \text { cut })\end{array}$ & $\begin{array}{l}\text { Cyclone } \\
(2-\mu \mathrm{m} \text { cut })\end{array}$ & $\begin{array}{l}\text { Flexible } \\
\text { plastic }\end{array}$ & 30 & 15 \\
$\begin{array}{l}\text { Cyclone } \\
(2-\mu \mathrm{m} \text { cut })\end{array}$ & $\begin{array}{l}\text { Storage } \\
\text { chamber }\end{array}$ & $\begin{array}{l}\text { Flexible } \\
\text { plastic }\end{array}$ & 60 & 15 \\
$\begin{array}{l}\text { Storage } \\
\text { chamber }\end{array}$ & $\begin{array}{l}\text { Mixing } \\
\text { box }\end{array}$ & $\begin{array}{l}\text { Flexible } \\
\text { plastic }\end{array}$ & 300 & 12 \\
$\begin{array}{l}\text { Mixing } \\
\text { box }\end{array}$ & $\begin{array}{l}\text { Exposure } \\
\text { chamber }\end{array}$ & $\begin{array}{l}\text { Vinyl } \\
\text { chloride }\end{array}$ & 90 & 60 \\
\hline
\end{tabular}

light-scattering detector (Model AP-638, Sibata Scientific Technology) connected to a storage chamber. This detector continuously monitored the dust concentration in the storage chamber. Dusts in the generator were aspirated from narrow grooves on the circular turntable with an output of $30 \mathrm{l} / \mathrm{min}$ of compressed air per min. Compressed air passed through a heatless air dryer (Model RDA-3 D, CKD Co. Ltd., Nagoya, Japan) before it was supplied to the dust generator. Its relative humidity and temperature were kept below $10 \%$ and at $23 \pm$ $4^{\circ} \mathrm{C}$, respectively. Dusts from the generator passed through two cyclone separators with an effective cut size of 5 and $2 \mu \mathrm{m}$ at an output of $30 \mathrm{l} / \mathrm{min}$ to increase the fraction of respirable dusts. The mass median aerodynamic diameter (MMAD) of reaerosolized dusts in the storage chamber with a volume of $1.73 \mathrm{~m}^{3}$ was reduced from 4.2 to $2.8 \mu \mathrm{m}$ by passage through two cyclones. Dusts in the storage chamber were aspirated into a stainless steel ejector by dry, compressed carrier air and diluted with filtered room air in the mixing box. Then they were introduced to the exposure chamber (see Fig. 2 ). The temperature of the room air averaged $23 \pm 3^{\circ} \mathrm{C}$ and its relative humidity ranged from 35 to $70 \%$.

Air flow through the exposure chamber was fixed at $150 \mathrm{l} / \mathrm{min}$ by a motor valve set between the exposure chamber and the exhaust blower.

The flow of filtered room air into the mixing box was dependent on the flow of air containing dusts through the ejector, since in this system both aspirated and compressed carrier air flow into an ejector depends on the dust concentration in the exposure chamber.

The exposure chamber was fabricated of stainless steel with glass windows. It had a volume of $0.45 \mathrm{~m}^{3}\left(80 \mathrm{~cm}^{2}, 70 \mathrm{~cm}\right.$ in height $)$ with a pyramidal top and bottom. Exhaust air was cleaned by passing through filters.

Materials, the length and inner diameter of the dust-supplying tubes connected each part to the exposure chamber are shown in Table 1.

Automatic control method: In this control system dust concentration in the exposure chamber is determined by aspirated air flow containing dusts from the storage chamber. Aspirated air flow depends upon the compressed carrier air flow through an ejector connected to the storage chmaber. A PID-controller (Model EC 5,000, Ohkura Electric Co. Ltd., Tokyo) and a mass flow controller (Model MF 4001, Ohkura Electric Co.) with a capacity of 0 to $50 \mathrm{l} / \mathrm{min}$ were used to regulate the compressed air flow automatically. Dust concentration in the exposure chamber was monitored continuously by another dust detector of the same type as that connected to the storage chamber. The PID-controller processed signals from this detector, fed control outputs to the mass flow controller and regulated the rate of compressed carrier air flow to the ejector (see Fig. 2).

Values of the proportional band, integral and derivative time stored in the PID-controller were first roughly calculated by the stepresponse method which is based on both the 
time to reach a set point when output from this controller is $100 \%$ and the time to return to a set point after overshooting. Then the optimum values were calculated by the ultimately sensitive method reported by Ziegler and Nichols [12]. The three values were proportional band $=90 \%:$ integral time $=3 \mathrm{~min}:$ derivative time $=$ $0.7 \mathrm{~min}$.

Experimental design and data collection: This study was designed to investigate the applicability of this automatic control system to dust inhalation and to confirm the presupposed improvements in control of dust concentration in an exposure chamber.

Dust concentration in the exposure chamber depends on both aspirated air flow from the storage chamber and the concentration of dust stored in the storage chamber. As stated above, aspirated air flow is controlled by compressed air flow. For this reason. in the first experiment the relationship between the stability of dust concentration in the exposure chamber and the compressed air flow rate was examined. In this experiment the relative concentrations in the storage chamber were changed from 800 to 4,500 counts per minute (CPM, obtained with a dust detector) and that in the exposure chamber was set at $300 \mathrm{CPM}$.

In the second experiment the effect of this automatic control (AC) method for the reduction of hunchings following on-off control of the dust generator was determined by comparing it with that of the constant air flow (CAF) method. In the CAF method the compressed carrier air flow to the ejector was kept at a constant flow rate under the optimal conditions obtained in the first experiment.

In the third experiment the build-up time to a set point after the beginning of exposure and the response to a sudden increase in dust concentration in the storage chamber, as a sham detachment of dusts adhering to the dustsupplying route, were investigated by the AC and CAF methods.

In these experiments the relative dust concentrations provided by the dust detectors connected to the storage and exposure chambers were recorded with a strip-chart recorder. A function printer (Model FP-1. Sibata Scinetific Technology) collected output signals from the dust detector every minute for 20 minutes and the geometric standard deviation (GSD) was calculated as an index of stability of the dust concentration.

In the fourth experiment the size distribution of particles and the spatial dust distribution in the exposure chamber at 0.1 to $5.0 \mathrm{mg} / \mathrm{m}^{3}$ were measured by the AC method.

In the subsequent experiment dusts stored in the storage chamber at the relative concentration of 2,300 CPM were introduced simultaneously into two exposure chambers by the AC method at a set point of 150 and $300 \mathrm{CPM}$ using two control units. Changes in dust concentration and the number of size-classified particles for up to 20 continuous hours of operation were measured.

In the final animal study of inhalation of coal fly ash at $2 \mathrm{mg} / \mathrm{m}^{3}$ (set point ; $288 \mathrm{CPM}$ ) was conducted for 180 days ( 20 hours/day, 7 days/week) by the AC method. In this study mass concentration was measured once a week and the GSD of the output signals from a dust detector collected every 15 minutes for 20 hours was calculated every day.

The mass concentration of dusts in the exposure chamber was measured at $20 \mathrm{l} / \mathrm{min}$ with a low-volume air sampler (Model L-20, Sibata Scientific Technology). Size distribution (MMAD, $\mu \mathrm{m}$ ) and its GSD of dusts in the exposure chamber were measured at the given time with a cascade impactor (Model AN-200, Dyrec Inc., Tokyo). Size-classified particles were counted with a light-scattering particle counter (Model KC-01, Rion Inc., Tokyo) .

\section{Results}

1. Stability of dust concentration in the exposure chamber : Table 2 shows the relationships between the GSD as an index of stability of dust concentration in the exposure chamber and the compressed air flow rate in the first experiment when the relative concentrations in the storage chamber were changed.

When the relative concentration in the storage chamber was set at $800 \mathrm{CPM}$, the dust concentration in the exposure chamber did not reach a set point of $300 \mathrm{CPM}$, because the required carrier air flow was greater than the capacity of the mass flow controller. With increasing concentration in the storage chamber, the relative concentration in the exposure chamber reached within $\pm 3 \%$ of a set piont. The most stable control was obtained at about $20 \mathrm{l} / \mathrm{min}$ of compressed air flow per min $(40 \%$ 
Table 2. Relationship between the stability of dust concentration in the exposure chamber and compressed air flow rate when the set point was set at $300 \mathrm{CPM}$ and the concentration in the storage chamber was changed

\begin{tabular}{|c|c|c|c|}
\hline $\begin{array}{l}\text { Concentration } \\
\left(\mathrm{CPM}^{*} \text {, storage }\right)\end{array}$ & $\begin{array}{l}\text { Average compressed } \\
\text { air flow }\left(\ell / \min ^{* *}\right)\end{array}$ & $\begin{array}{l}\text { Concentration } \\
\text { (CPM, exposure) }\end{array}$ & $\begin{array}{c}\mathrm{GSD}^{* * *} \\
\text { (exposure) }\end{array}$ \\
\hline 4500 & 12.0 & 298 & 1.00374 \\
\hline 3400 & 14.5 & 297 & 1.00442 \\
\hline 2800 & 16.0 & 298 & 1.00273 \\
\hline 2300 & 19.5 & 299 & 1.00234 \\
\hline 1800 & 24.5 & 297 & 1.00473 \\
\hline 1200 & 35.5 & 293 & 1.00670 \\
\hline 800 & 50.0 & 219 & 1.02175 \\
\hline
\end{tabular}

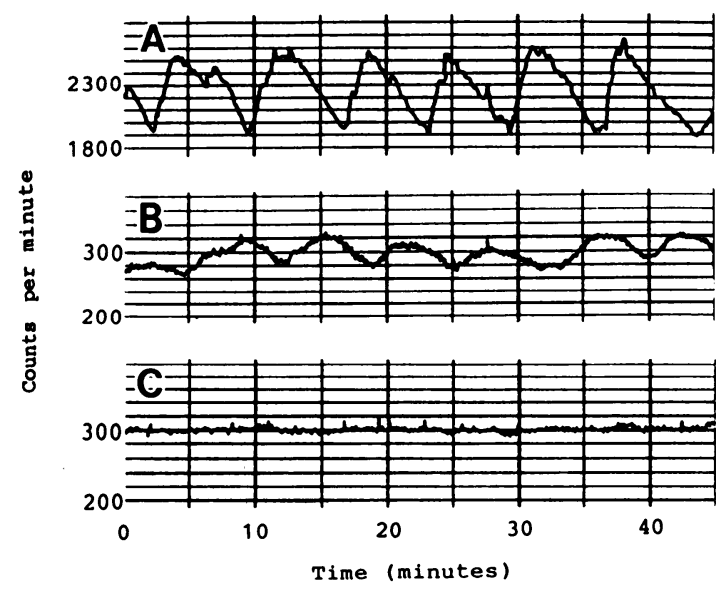

Fig. 3. Chart recordings of dust concentration provided by a light scattering dust detector. A shows dust concentration in the storage chamber set at $2300 \mathrm{CPM}$. B and $\mathrm{C}$ show the changes in dust concentration in the exposure chamber by the constant air flow method (CAF) and by automatic control method (AC) set at $300 \mathrm{CPM}$, respectively .

of the capacity of the mass flow controller) and a relative concentration of $2,300 \mathrm{CPM}$ in the storage chamber.

2. Reduction of hunchings following on-off control of the dust generator:Differences in dust concentration measured by the $\mathrm{AC}$ method and by the CAF method are shown in Fig. 3 . The AC method caused significantly fewer hunchings followed by those in the storage chamber compared with the CAF method. The average, maximum and minimum values of the
Table 3. Average, maximum, and minimum values of the geometric standard deviation of output signals collected with a dust detector every minute for 20 minutes by the constant air flow method (CAF) and by the automatic control method (AC)

\begin{tabular}{lcc}
\hline & CAF & AC \\
\hline No. of samples & 20 & 20 \\
Average & 1.01363 & 1.00243 \\
Maximum & 1.03934 & 1.00353 \\
Minimum & 1.00449 & 1.00150 \\
\hline
\end{tabular}

GSD calculated from output signals from the dust detector by the AC method were smaller than those by the CAF method (Table 3 ) .

3 . Build-up time and response to sudden increase in dust concentration: Fig. 4 shows the build-up changes in dust concentration in the exposure chamber to a set point obtained by the CAF method (lower line) or by the AC method (upper line) at $100 \%$ of the output limit from the PID-controller to the mass flow controller (Superimposed on an identical chart for comparison) .

The average build-up time (T1) by the CAF method and the AC method were 743 and 170 seconds, respectively. However, the AC method caused overshooing of dust concentration after reaching a set point and the recovery time (T2) was $791 \mathrm{sec}$ onds. When the output limit was decreasd, T1 bacame longer. However, the degree of overshooting decreased and $\mathrm{T} 2$ bacame shorter. This experiment indicates that the output limit without overshooting was $70 \%$ and the average $\mathrm{T} 1$ was 557 seconds 


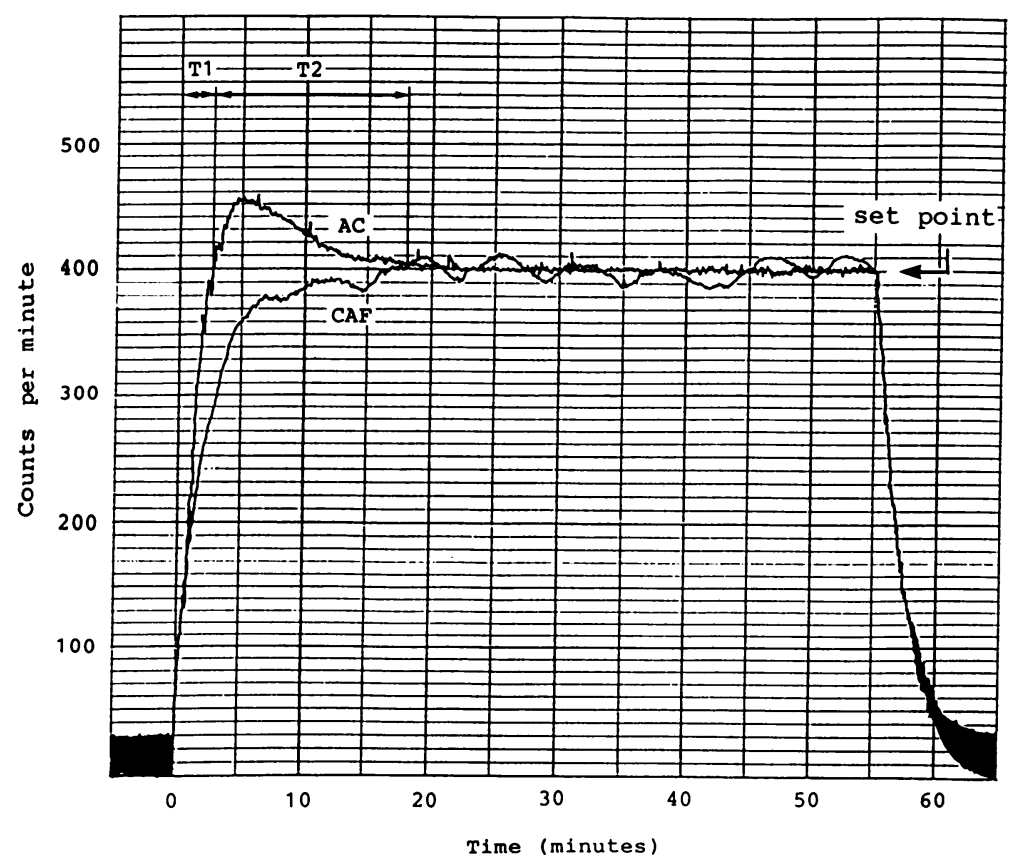

Fig. 4. Build-up time ( $\mathrm{T} 1)$ and recovery time ( $\mathrm{T} 2)$ by the automatic control method (AC : upper line) at $100 \%$ of the output limit from a PID -controller to a mass flow controller and by the constant air flow method (CAF : lower line). This figure was superimposed on another chart.

Table 4. Summary of build-up time (seconds, T1) and recovery time (T2) by the constant air flow method (CAF) and by the automatic control method (AC) at 60 to $100 \%$ of the output limit from the PID-controller

\begin{tabular}{lcccc}
\hline Method & $\begin{array}{l}\text { No. of } \\
\text { trials }\end{array}$ & $\begin{array}{c}\text { Percent of } \\
\text { output limit }\end{array}$ & $\begin{array}{c}\text { T1 } \\
\text { (mean } \pm \text { S.D.) }\end{array}$ & $\begin{array}{c}\text { T2 } \\
\text { (mean } \pm \text { S.D.) }\end{array}$ \\
\hline CAF & 5 & & $743 \pm 44$ & 0 \\
AC & 5 & 100 & $170 \pm 24$ & $791 \pm 56$ \\
AC & 5 & 90 & $226 \pm 26$ & $666 \pm 48$ \\
AC & 5 & 80 & $374 \pm 84$ & $422 \pm 45$ \\
AC & 5 & 70 & $557 \pm 27$ & 0 \\
AC & 5 & 60 & $786 \pm 35$ & 0 \\
\hline
\end{tabular}

(Table 4).

Fig. 5 shows the changes in dust concentration in the exposure chamber when the dust concentration in the storage chamber was increased artificially. Dust concentration measured by the CAF method (left, Fig. 5) changed similarly to that in the storage chamber. On the other hand, the AC method (right) reduced the overshooting.

4. Size distribution of particles and spatial dust distribution in the exposure chamber: The GSD of size distribution of particles in the exposure chamber increased slightly with rising dust concentration. However, the MMAD ran- ged between 2.4 and $2.5 \mu \mathrm{m}$ at any set point of dust concentration in the exposure chamber (Table 5) .

Spatial dust distribution in the exposure chamber was homogeneous and its deviation was less than $2 \%$ of the mean concentration (data not presented).

5 . Changes in dust concentration and sizeclassified particle number for 20 hours of operation : Simultaneous dust exposure in two exposure chambers at the relative concentrations of 150 and $300 \mathrm{CPM}$ for 20 continuous hours were kept constant in the $\mathrm{AC}$ method as shown in Fig. 6. The number of size-classified particles 

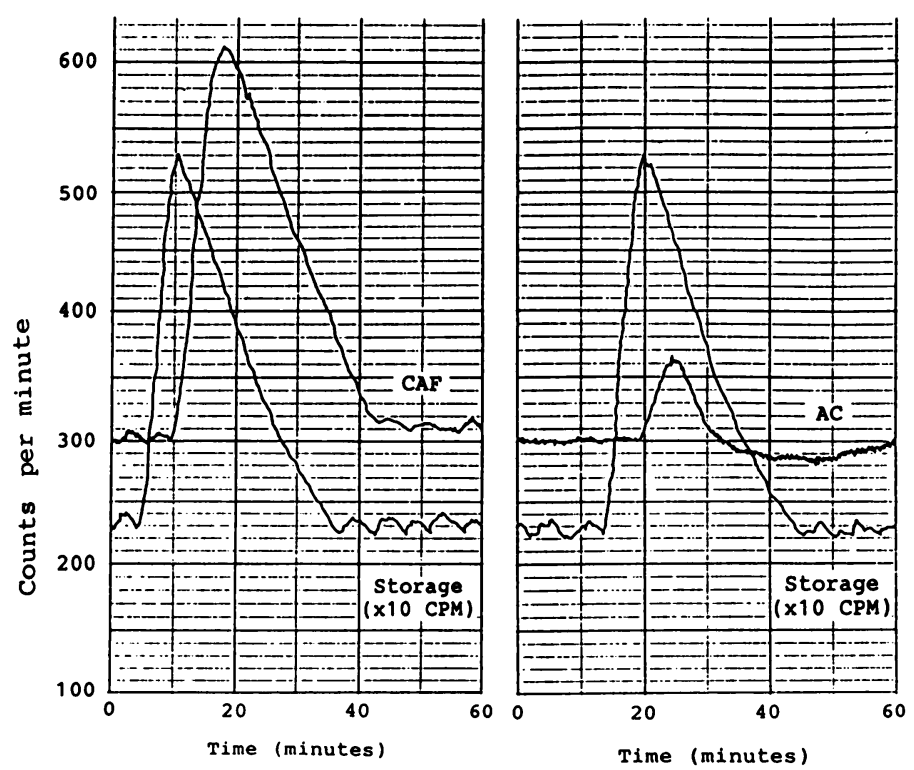

Fig. 5. Changes in dust concentration measured by the automatic control method ( $\mathrm{AC}:$ right) and by the constant air flow method (CAF : left) when a transient increase occurred in the storage chamber.

Table 5. Mass median aerodynamic diameter (MMAD) and geometric standard deviation (GSD) at several dust concentrations

\begin{tabular}{cccc}
\hline $\begin{array}{c}\text { Concentration } \\
\left(\mathrm{mg} / \mathrm{m}^{3}\right)\end{array}$ & $\begin{array}{c}\text { No. of } \\
\text { samples }\end{array}$ & $\begin{array}{c}\text { MMAD } \\
(\mu \mathrm{m})\end{array}$ & GSD \\
\hline 0.1 & 5 & 2.4 & 1.36 \\
0.2 & 5 & 2.5 & 1.33 \\
0.4 & 5 & 2.5 & 1.34 \\
1.0 & 6 & 2.4 & 1.37 \\
2.0 & 6 & 2.4 & 1.49 \\
5.0 & 6 & 2.5 & 1.53 \\
\hline
\end{tabular}

was also constant and the deviation of each size was less than $5 \%$ (data not shown).

6. Regulatory performance for 180 days: Daily values of the GSD of output signals from the dust detector collected every 15 minutes for 20 hours are shown in Fig. 7. For 180 days of operation at the nominal dust concentration of $2 \mathrm{mg} / \mathrm{m}^{3}$, the AC method maintained a stable dust concentration in the exposure chamber throughout the experiment. The mass concentration measured once a week was $2.0 \pm 0.14$ $\mathrm{mg} / \mathrm{m}^{3}$.

\section{Discussion}

Since it is difficult to generate dusts stably
[2], dust aerosols are usually generated by an on-off control system. This control method causes hunchings. Sudden disturbances in concentration are liable to occur in dust inhalation studies since dust adhering to the dust-supplying route would detach and disperse during the operation. A PID-controller can adjust control variables to a set point quickly, eliminate the offset, and respond to sudden changes by automatic $\mathrm{P}^{-}, \mathrm{I}^{-}$, and $\mathrm{D}$-action, respectively. $\mathrm{A}$ mass flow controller can adjust the gas flow rate quickly and accurately. For these reasons, a new dust inhalation system including two feedback systems was developed by introducing both PID- and mass flow controllers in order to regulate the air flow from the storage chamber to the exposure chamber by using compressed carrier air in an ejector as exposure air.

As expected, with this AC method the build-up time to a set point was shorter than that with the CAF method (Table 4). Fig. 3 demonstrates that this method could reduce hunchings following on-off control of the dust generator. Figs. 6 and 7 show that this method could also keep the dust concentration close to a set point for a long time. These results indicate that this control method is suitable not only for short-term but also long-term dust 


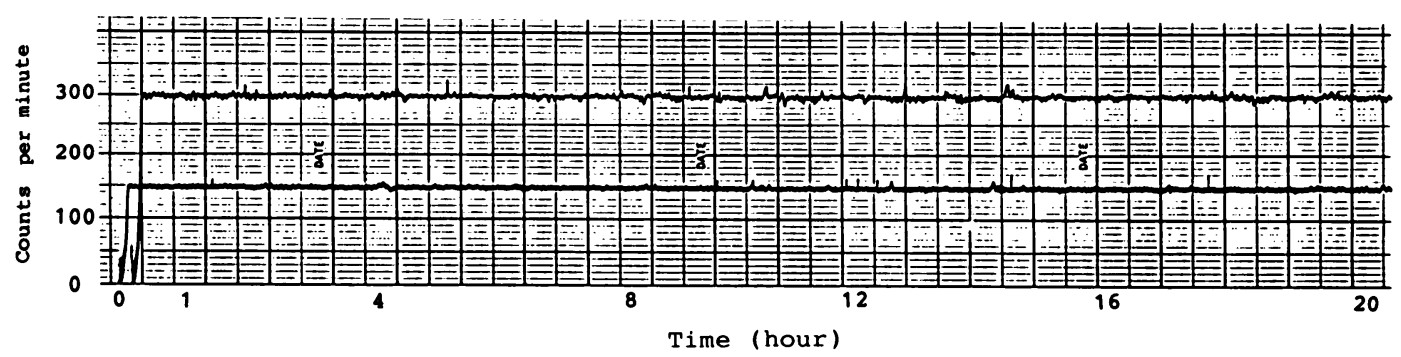

Fig. 6. Recording of dust concentration in two exposure chambers for 20 continuous hours of operation provided by a light scattering dust detector. Dusts stored in one storage chamber were introduced into two exposure chambers simultaneously by the $\mathrm{AC}$ method using two control units. Upper and lower lines were set at 300 and $150 \mathrm{CPM}$, respectively.

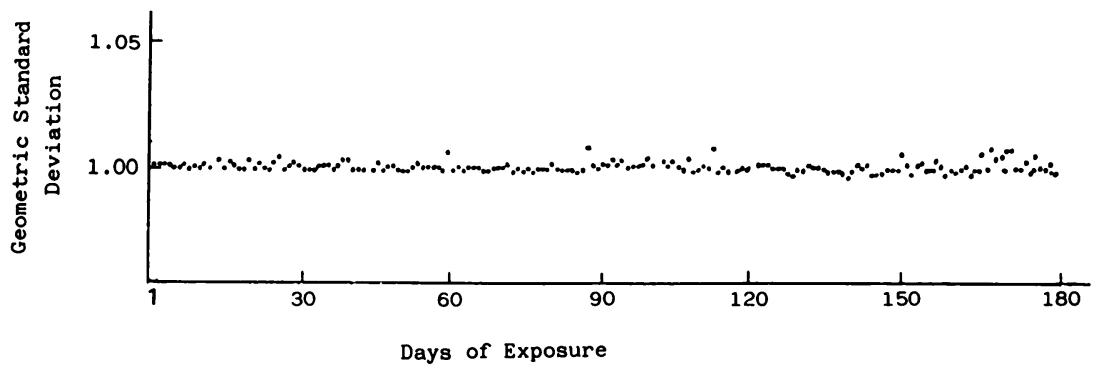

Fig. 7. Changes in geometric standard deviation of output signals from a dust detector collected every 15 minutes for 20hours during 180days of animal inhalation of coal fly ash at the relative concentration of $288 \mathrm{CPM}$.

inhalation studies.

As shown in Fig. 5, this AC method responded to sudden disturbances quickly and could have less overshooting than the CAF method.

Table 2 shows that in this system the most stable control was obtained at about $40 \%$ of the capacity of the mass flow controller. This result suggests that the relationships between dust concentrations in the storage and exposure chambers and the capacity of the mass flow controller should be considered before the inhalation system is set up in order to stabilize the dust concentration in the exposure chamber. However, this table also shows that the AC method could maintain a stable dust concentration close to the set point even if the dust concentraion in the storage chamber shifts within some limited range from the optimum one. In addition, this control system could introduce different doses of dust to different exposure chambers simultaneously if additional identical exposure units are set as shown in Fig. 6
Table 5 shows that the MMADs of dusts at the concentration of 0.1 to $5 \mathrm{mg} / \mathrm{m}^{3}$ were maintained between 2.4 and $2.5 \mu \mathrm{m}$. This result might be due to the effects of two cyclone separators set between the dust generator and the storage chamber in order to reduce the coarse dust particles. This system was also demonstrated to be applicable to dust inhalation studies to investigate a dose-response relationship.

Since compressed carrier air flow in this $\mathrm{AC}$ method reaches the maximum just after the beginning of exposure by the $\mathrm{P}$-action mode of the PID-controller, dusts adhering to the dustsupplying route would be liable to detach at this time. Therefore, these adhering dusts, especially those on the inner surface of the tube from an ejector to a mixing box, should be removed before initiation of the next exposure.

The authors wish to thank Drs. Y. Hayashi and M. Kurohmaru at the University of Tokyo, Drs. O. Matsuoka and Y. Kohno at the Central Research Institute of Electric Power Industry for their encouragement and useful discussion. The authors also thank Mr. A. Miyabayashi (Sibata 
Scientific Technology Ltd.) for his technical cooperation, and Mrs. T. Kubo and Mrs. E. Hama for their technical assistance.

\section{References}

[1] Adamson, I. Y. R. and Bowden, D. H. (1981). Dose response of the pulmonary macrophagic system to various particulates and its relationship to transepithelial passage of free particles.

Exp. Lung Res., 2. 165-175.

[2] Davis, J. W. and Iriwin, V. C. (1982). A dry dust generator system for animal exposures at controlled concentrations. Am. Ind. Hyg Assoc. J., 43, 704-711.

[3] Gross, P., deTreville, R. T. P., Tolker, E. B., Kaschak, M., and Babyak, M. A. (1969). The pulmonary macrophage response to irritants. Arch. Environ. Health, 18, 174-185.

[4] Hirano, S. (1987). Automatic control of aerosol concentrations in exposure chambers. Am. Ind. Hyg . Assoc. J., 48, 972-976.

[5] Katsnelson, B. A. and Privalova, L. I. (1984). Recruitment of phagocytizing cells into the respiratory tract as a response to the cytotoxic action of deposited particles. Environ. Health Perspec., 55, 313-325.

[6] Morgan, A., Moores, S. R., Holmes, A., Evans, J. C., Evans, N.H., and Black, A. (1980). The effect of quartz administered by intratracheal instillation on the rat lung. I. The cellular response. Environ. Res., 22, 1-12.

[7] Raabe, O.G., Yeh, H-C., Newton, G. J., Phalen, R. F. and Velasquez, D.J. (1977). Deposition of inhaled monodisperse aerosols in small rodents. In Inhaled Particles IV, pt. 1,pp.3-21. W. H. Walton (ed.), Oxford, Pergamon.

[8] Rudolf, G., Gebhart, J., Heyder, J., Schiller, Ch. F., and Stahlhofen, W. (1986). An empirical formula describing aerosol deposition in man for any particle size. J. Aerosol Sci., 17, 350-355.

[9] Stahlhofen, W., Gebhart, J., and Heyder, J. (1980). Experimental determination of the regional deposition of aerosol particles in the human respiratory tract. Am. Ind. Hyg. Assoc. J., 41, 385-398.

[10] Strom, K. A. (1984). Response of pulmonary cellular defenses to the inhalation of high concentration of diesel exhaust. J. Toxicol. Environ. Health, 13, 919-944.

[11] Thomson, S. M., Burnett, D. C., Bergmann, J. D., and Hixson, C. J. (1986). Comparative inhalation hazards of aluminium and brass powders using bronchopulmonary lavage as an indicator of lung damage. J. Appl. Toxicol., 6, 197-209.

[12] Ziegler, J. G. and Nichols, N. B. (1942) . Optimum settings for automatic controllers. Trans. A. S. M. E., 64, 759-768.

\title{
実験小動物用のダスト吸入暴露システム
}

\author{
根岸正・西村 泉
}

電力中央研究所生物部

ガス状物質と比較するとタストを安定して発生さ せることは困難であるため, 動物吸入暴露実験にお いて暴露チャンバー内のダスト濃度を一定に保つこ とは難しい。本研究ではダストの暴露濃度を安定さ せるために, 発生器の制御はon-off コントロールの みで行い，発生させたダストを 2 台のサイクロン整 粒器を通過させた後一旦貯蔵漕に蓄え，ここから暴 露チャンバーへ搬送するタスト供給量を自動調節す る方法を採用した。本システムでは, 貯蔵漕内の夕 ストを加圧空気によってエジェクターへ吸い上げさ せ, 混合漕で清浄空気と希釈・混合させた後, 暴露 チャンバーに導入した。暴露チェンバー内のタスト 濃度は加圧空気によってエジェクターに吸い上げら れるダトの量によって決まる。このため, 暴露
チェンバーに取り付けた光散乱方式による粉塺計か らの濃度信号をPIDコントローラーで処理させ, ガス 流量調節用のマスフローコントローラーに制御信号 を送り，加圧空気の量を自動的に制御させた。本制 御システムは, 発生器のon-off コントロールによる ハンチンクを低減するとともに，ダストの暴露濃度 を長時間にわたり安定して維持することができた。 また，所定濃度に達するまでの時間を短縮し，タス 卜暴露に特有な配管内部に付着したタストの剥離に よる急激な濃度上昇も軽減することができた。さら に, 本暴露システムは複数のチャンバーに異なる濃 度のタストをタストの中位径を変化させることなく 同時に暴露できることが明らかとなった。 